\title{
PEMBENTUKAN INDEKS KETAHANAN AIR RUMAH TANGGA DI INDONESIA MENURUT LIMA ASPEK KETAHANAN AIR UN-WATER TAHUN 2018
}

\author{
(Formation of Household Water Security Index in Indonesia According to Five Aspects of \\ UN-Water Water Security in 2018)
}

\section{Uzlifatul Jannah¹, Siti Muchlisoh²}

\author{
Politeknik Statistika STIS ${ }^{1}$ \\ Politeknik Statistika STIS² \\ Jl. Tanjung Pangimpuan, Kota Palu, Sulawesi Tengah \\ E-mail: 111710037@stis.ac.id
}

\begin{abstract}
ABSTRAK
Salah satu tujuan SDG's keenam adalah pada tahun 2030 mewujudkan 100 persen akses universal dan merata kepada air minum aman dan sanitasi yang terjangkau bagi semua. Secara umum, definisi ketahanan telah ada dan dirumuskan oleh UN-Water (2013), dimana ada enam aspek yang terkandung didalamnya. Belum ada suatu ukuran di Indonesia mengenai ketahanan air rumah tangga. Untuk mengetahui dan menggambarkan kondisi ketahanan air rumah tangga di Indonesia diperlukan indeks yang sampai saat ini belum tersedia yaitu Indeks Ketahanan Air Rumah Tangga (IKART) dengan mengacu kepada definisi ketahanan air UN-Water. Metode pembentukan indeks yang digunakan mengacu pada metode yang dikembangkan oleh OECD (2008) dengan menggunakan analisis faktor. Hasil yang diperoleh dari analisis faktor terbentuk dua faktor, yaitu faktor sarana air dan faktor sosial-ekonomi. Secara keseluruhan IKART yang dimiliki Indonesia sebesar 58,20 dan berada pada tingkatan cukup terpenuhi kebutuhan air rumah tangga. Papua menjadi provinsi dengan IKART terendah yaitu sebesar 9,56, sedangkan provinsi dengan IKART tertinggi adalah DKI Jakarta sebesar 83,82.
\end{abstract}

Kata kunci: ketahanan, air, indeks, eksploratori, cukup.

\begin{abstract}
One of the six SDG's goals is by 2030 to achieve 100 percent universal and equitable access to safe drinking water and sanitation that is affordable for all. In general, the definition of resilience already exists and was formulated by UN-Water (2013), where there are six aspects contained therein. There is no single measure in Indonesia regarding household water resistance. To know and describe the condition of household water resistance in Indonesia, an index that is not yet available is needed, namely the Household Water Resistance Index (IKART), which refers to the definition of water resistance at UN-Water. The index formation method used refers to the method developed by the OECD (2008) using factor analysis. The results obtained from the factor analysis formed two factors, namely the water supply factor and the socioeconomic factor. Overall, the IKART owned by Indonesia is 58.20 and is at a sufficient level for household water needs to be met. Papua was the province with the lowest IKART, which was 9.56, while the province with the highest IKART was DKI Jakarta at 83.82.
\end{abstract}

Keywords: security, water, index, exploratory, sufficient. 


\section{PENDAHULUAN}

Air merupakan sumber daya yang vital bagi kehidupan. Tidak hanya penting bagi manusia, air merupakan bagian yang penting bagi makhluk hidup lain seperti hewan maupun tumbuhan. Tujuan Pembangunan Berkelanjutan (SDG's) memasukkan air sebagai salah satu target pembangunan di dalam poin ke-enam. Salah satu isi dari target tersebut adalah mewujudkan 100 persen akses universal dan merata kepada air minum dan sanitasi yang terjangkau bagi semua di tahun 2030. Umumnya air digunakan untuk kegiatan sehari - hari rumah tangga seperti minum, mandi, memasak, maupun mencuci. Dalam usaha memenuhi kebutuhan air dalam kehidupannya, manusia berupaya mengadakan air yang cukup bagi dirinya. Oleh karena itu, penting untuk memastikan pasokan air bersih dan layak bagi ketahanan air di masa yang akan datang.

Organisasi dunia yang bergerak dibidang air dan sanitasi, (UN-Water, 2013) telah merumuskan bahwa ketahanan air merupakan kemampuan masyarakat untuk menjaga keberlanjutan dalam pemenuhan kebutuhan air, baik dalam jumlah yang mencukupi serta yang yang dapat diterima untuk menjaga keberlangsungan hidup; kesejahteraan umat manusia; perkembangan sosial-ekonomi; menjamin perlindungan atas pencemaran air dan bencana terkait air; serta melestarikan ekosistem dalam suasana damai dan kondisi politik yang stabil. UN-Water juga mendukung dimasukkannya ketahanan air dalam agenda Dewan Keamanan PBB dan dalam agenda pembangunan pasca-2015 sebagai bagian dari Tujuan Pembangunan Berkelanjutan (SDG's).

Menurut (Amron, 2010), ketahanan air memiliki konsep yang lebis luas daripada ketersediaan air yaitu upaya mendapatkan air, keamanan dari daya rusak dan penyediaan air yang berkelanjutan. Ketahanan air dikaitkan dengan empat hal yakni aksesibilitas, berkelanjutan, keamanan dan ketersediaan potensi air. Sedangkan, kajian yang dilakukan oleh Asian Development Bank (ADB) dan Asia Pacific Water Forum (APWF) pada tahun 2013 merumuskan lima dimensi ketahanan air yaitu ketahanan air rumah tangga, ketahanan air ekonomi, ketahanan air perkotaan, ketahanan air lingkungan, dan ketahanan terhadap bencana terkait air. Salah dari lima dimensi tersebut, yaitu ketahanan air rumah tangga dikaji karena fondasi dan landasan dalam ketahanan air adalah apa yang terjadi di tingkat rumah tangga. Ketahanan air rumah tangga menjadi fondasi penting dalam upaya pengentasan kemiskinan dan mendukung pembangunan ekonomi. Akses saluran air rumah tangga dan akses sanitasi layak menjadi pembahasan penting dalam ketahanan air rumah tangga. ADB juga menyatakan bahwa akses saluran air rumah tangga di Indonesia hanya sebesar 20 persen. Pada Kawasan Asia Tenggara, Indonesia menempati posisi ketiga dari bawah, bahkan persentase tersebut sedikit lebih rendah dari negara Timor-Leste yang memiliki persentase sebesar 21 persen. Untuk akses sanitasi di kawasan Asia Tenggara, Indonesia juga menempati posisi ketiga dari bawah yaitu hanya sebesar 54 persen rumah tangga yang memiliki akses sanitasi (ADB, 2013).

Pentingnya akses air dan akses sanitasi bagi kehidupan masyarakat Indonesia demi ketahanan air rumah tangga, membuat pemerintah mengeluarkan undang-undang yang mengatur tentang sumberdaya air. Undang-Undang Nomor 17 Tahun 2019 Tentang Sumber Daya Air (diperbarui dari UU No. 7 Tahun 2004) dalam Bab III Pasal 6 berbunyi:

"Negara menjamin hak rakyat atas Air guna memenuhi kebutuhan pokok minimal sehari-hari bagi kehidupan yang sehat dan bersih dengan jumlah yang cukup, kualitas yang baik, aman, terjaga keberlangsungannya, dan terjangkau." 
Masyarakat dunia sepakat bahwa ketahanan air perlu diperhatikan, namun belum ada kesepakatan dalam mendefinisikan ketahanan air dan bagaimana mengukur nilai ketahanan air minimum untuk mencapai ketahanan air yang maksimal. Untuk melihat seberapa jauh gambaran ketahanan air rumah tangga di Indonesia, sehingga diperlukan indeks yang dapat menjawab permasalahan tersebut. Belum tersedianya indeks ketahanan air rumah tangga di Indonesia membuat penulis tertarik untuk membentuk indeks berdasarkan definisi ketahanan air yang telah ditetapkan oleh UN-Water.

\section{METODE}

\section{Analisis Faktor}

Analisis faktor merupakan salah satu analisis multivariat yang dipergunakan untuk mereduksi atau meringkas data. Dari data yang awalnya memiliki banyak variabel diubah menjadi sedikit variabel dan masih memuat informasi yang terkandung pada variabel asli. Tujuan umum dari analisis faktor untuk mereduksi banyak variabel-variabel yang saling berkorelasi, lalu diperkecil jumlah variabelnya agar dapat dengan mudah dikelola (Supranto, 2004). Analisis faktor eksploratori (Exploratory Factor Analysis, EFA) memiliki pola keterkaitan antar variabel dapat diketahui melalui nilai kovarians antar variabel tersebut. Pada dasrnya tujuan analisis faktor eksploratori adalah mengelompokkan variabel-variabel berdasarkan nilai korelasi antar variabel, sehingga membentuk variabel baru dengan jumlah varibel yang sedikit. Pada analisis faktor, terdapat vektor acak $y_{i}=\frac{0,8602\left(x_{i}\right)}{z_{i}} \times \frac{10.000 \mathrm{~m}^{2}}{1.000 \mathrm{~kg}}$ yang mempunyai vektor rata-rata dan matriks kovarians $\Sigma$, secara linier bergantung pada sejumlah faktor yang teramati. faktor-faktor umum (common factors) dan $\mid$ thitung $\mid$ disebut faktor-faktor khusus (specific factors).

Model analisis faktor:
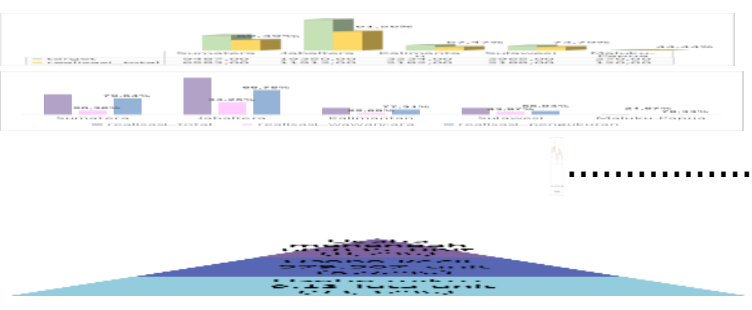

dimana:

$$
\begin{aligned}
& =\text { nilai variabel asal } \\
& =\text { faktor umum; } \mathrm{j}=1,2, \ldots, \mathrm{m} ; \mathrm{m}<\mathrm{p} \\
& =\text { faktor spesifik; } \mathrm{i}=1,2, \ldots, \mathrm{p} \\
& \mathrm{m} \quad=\text { faktor loading dari variabel ke-i pada faktor ke- } \mathrm{j} \\
& \mathrm{p} \quad=\text { rata-rata variabel ke-i } \\
& \quad=\text { banyaknya variabel asal }
\end{aligned}
$$




\section{Tahapan Analisis Faktor}

Menurut (Asra et al., 2017), tahapan dalam melakukan analisis faktor eksploratori terbagi menjadi empat, sebagai berikut:

1. Menguji Kelayakan Data

Langkah awal ketika melakukan analisis faktor adalah terlebih dahulu dilakukan pemeriksaan pada data. Dalam pemeriksaan data untuk mengetahui keterkaitan secara empiris dapat dilakukan dengan beberapa uji, yaitu:

a. Korelasi sederhana

Mengolah data untuk mengetahui korelasi antar pasangan variabel menjadi matriks korelasi. Kemudian, nilai korelasi digunakan untuk melakukan beberapa uji untuk melihat kesesuaian dengan nilai korelasi yang diperoleh dari analisis faktor.

b. Measure of Sampling Adequacy (MSA) dan Keiser-Meyers-Oklin (KMO)

i. MSA, merupakan indeks yang digunakan untuk mengukur hubungan antar variabel yang akan diteliti. Nilai MSA yang mendekati 1 menunjukkan bahwa nilai suatu variabel dapat diprediksi oleh variabel lainnya dengan kesalahan yang kecil. Menurut (Anderson et al., 2008) dalam (Asra et al., 2017), bahwa MSA yang kurang dari 0,5 menunjukkan hubungan antar variabel tersebut dengan variabel lainnya tidak kuat, sehingga variabel tersebut tidak dapat dianalisis lebih lanjut menggunakan analisis faktor atau tidak diikutsertakan dalam analisis.

ii. KMO, merupakan indeks yang digunakan untuk membandingkan koefisien korelasi pengamatan dengan koefisien korelasi parsial. (Anderson et al., 2008) dalam (Asra et al., 2017) menyatakan bahwa nilai KMO yang kecil menunjukkan bahwa pemilihan variabel yang akan diteliti dalam analisis faktor belum sesuai. Uji keterkaitan variabel dengan

\section{c. Bartlett Test of Sphericity}

Uji bartlett adalah uji yang digunakan untuk melihat keberartian korelasi antar variabel, sehingga variabel yang akan diteliti tersebut dapat dianalisis lebih lanjut menggunakan analisis faktor.

\section{Ekstraksi Faktor}

Ekstraksi faktor terbentuk dari himpunan faktor sebagai transformasi dari peubahpeubah asal berdasarkan hubungan linier terbaik. Metode dalam ekstraksi faktor diantaranya yaitu Analisis Komponen Utama (AKU), faktor utama, analisis citra, faktor kanonik iterasi Haris, Maximum Likelihood Estimation, ataupun Unweighted Least Square. Analisis Faktor merupakan perluasan dari AKU yang bertujuan untuk mendapatkan sejumlah kecil faktor dan memiliki sifat sebagai berikut: menjelaskan keragaman data, antar faktor saling bebas, dan setiap faktor diinterpretasikan dengan jelas. Terdapat beberapa kriteria yang terbaik, yaitu: (1) Kriteria akar ciri (eigenvalue) $\geq 1$, (2) Kriteria persentase varians, yaitu memperhatikan persentase varians yang diekstraksi oleh faktor-faktor yang terpilih $\geq 60$ persen, (3) Kriteria Scree Plot, yaitu merupakan kriteria dari plot antara total faktor yang terbentuk (pada sumbu $\mathrm{x}$ ) dengan nilai akar ciri (sumbu y).

3. Rotasi Faktor

Kesulitan dalam memperoleh faktor-faktor dari komponen utama, seringkali membuat suatu peubah nampak tidak mempunyai korelasi dengan faktor manapun. Sedangkan tujuan dari analisis faktor adalah untuk memperoleh faktor yang berisi peubah-peubah yang mempunyai korelasi yang tinggi satu sama lain. Maka dari itu dilakukan rotasi terhadap matriks loading $L$, sehingga menghasilkan matriks loading baru $L^{*}$. 
4. Interpretasi Faktor yang terbentuk

Nilai yang diinterpretasikan dalam analisis faktor antara lain:

- Nilai faktor loading adalah angka yang menunjukkan besarnya korelasi antara suatu variabel dengan faktor lainnya yang terbentuk.

- Nilai komunalitas, diinterpretasikan sebagai nilai peran faktor dalam menjelaskan keragaman variabel asal ke-i dengan satuan persen.

- Penentuan variabel sebagai komponen utama pembentuk faktor tertentu, dilakukan dengan membandingkan besar korelasi/loading faktor pada setiap baris di dalam setiap tabel/matriks komponen loading.

- Nama-nama faktor yang terbentuk berdasarkan faktor loading suatu variabel terhadap faktor pembentuknya.

\section{Agregasi}

Agregasi merupakan proses penyusunan indeks dari berbagai indikator tersedia. Dalam penelitian ini, agregasi dilakukan dengan menjumlahkan perkalian penimbang masing-masing faktor dengan skor faktor masing-masing provinsi setelah dinormalisasi. Berikut agregasi menurut (OECD, 2008) yang akan dibentuk:

dimana:

$$
\begin{aligned}
& =\text { Indeks Ketahanan Air provinsi ke-n } \\
& =\text { penimbang faktor ke-j } \\
& \text { = skor faktor provinsi ke-n pada faktor ke-j setelah di normalisasi } \\
& y_{i}=\beta_{0}+\beta_{1} x_{1 i}+\beta_{2} x_{2 i}+\varepsilon_{i} \\
& y_{t}=\beta_{0}+\beta_{1} x_{i}+\beta_{2} x_{2}+\rho \sum_{j=1}^{n} w_{i} y_{y}+u_{i} \quad=\text { Indeks Ketahanan Air Indonesia } \\
& =\text { Indeks Ketahanan Air provinsi ke-n, } \mathrm{n}=1,2, \ldots, 32 \\
& \mathrm{n}=\text { jumlah provinsi }
\end{aligned}
$$

\section{Pengelompokkan Provinsi}

Dalam mempermudah analisis ketahanan air, provinsi-provinsi tersebut dikelompokkan berdasarkan indeksnya. Tujuan pengelompokan provinsi tersebut agar dapat menganalisa keparahan kondisi setiap provinsi yang memiliki karakteristik yang sama. Pengelompokan provinsi akan dibagi menjadi tiga kategori berdasarkan Quartil dari indeks tersebut (Faradis \& Afifah, 2020). Berikut pengelompokkan provinsi tersebut:

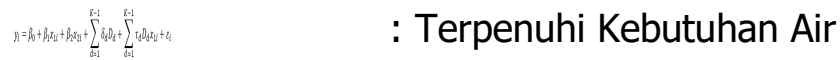

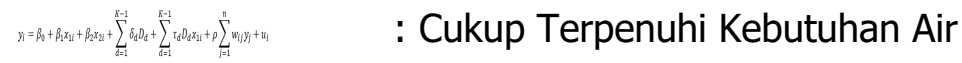




\section{Ketahanan Air}

UN-Water (2013) merumuskan bahwa Ketahanan air merupakan kemampuan masyarakat untuk menjaga keberlanjutan dalam pemenuhan kebutuhan air, baik dalam jumlah yang mencukupi serta yang dapat diterima untuk menjaga keberlangsungan hidup, kesejahteraan umat manusia, perkembangan sosial-ekonomi, menjamin perlindungan atas pencemaran air dan bencana terkait air, serta melestarikan ekosistem dalam suasana damai dan kondisi politik yang stabil.

\section{Kerangka Indikator Ketahanan Air}

Pada tahun 2013, UN-Water merumuskan sebuah definisi ketahanan air. Definisi tersebut memuat dimensi atau unsur-unsur dari kemampuan yang akan diperoleh masyarakat dari ketahanan air.

1. Pemenuhan kebutuhan air dan menjaga keberlangsungan hidup

Air sudah menjadi kebutuhan vital dan paling penting bagi umat manusia di seluruh dunia dalam menjaga keberlangsungan hidup. Untuk itu akses terhadap air sudah menjadi hak dasar manusia dan pemenuhan akan kebutuhan air bukan saja menjadi agenda nasional, tetapi sudah menjadi agenda dunia dengan dibuatnya program-program pembangunan berkelanjutan yang tertuang dalam SDGs (Sustainable Development Goals). Dalam SDGs, target pemenuhan air harus tercapai 100 persen pada 2030. Memenuhi target kebutuhan air tersebut dimulai dari akses ke sumber air itu sendiri. Dalam penelitian (Messakh et al., 2015) yang dilakukan di NTT bahwa potensi sumber air yang ada menjadi prioritas utama dalam terpenuhinya kebutuhan akan air minum.

2. Kesejahteraan umat manusia

a. Akses terhadap sanitasi layak

Kesejahteraan dapat diartikan dengan kondisi suatu masyarakat yang sudah membaik dan stabil. Pengukuran kesejahteraan sangat relatif, bergantung pada kondisi yang akan diharapkan pada permasalahan tertentu. Dalam hal ketahanan air, kesejahteraan bisa menjadi pencapaian dari kondisi baik dan stabil yang dialami oleh masyarakat terhadap air. Kata lain, saat krisis air sudah tidak terjadi atau minim, maka masyarakat sudah dianggap sejahtera. Menurut BPS, dari segi kesehatan, tingkat kesejahteraan dapat diukur melalui rumah tangga yang memiliki akses terhadap layanan sanitasi layak. Sanitasi sangat erat kaitannya dengan air, tercapainya sanitasi yang baik menandakan terjadinya pengelolaan air bersih.

b. Fasilitas cuci tangan dengan sabun dan air

Risnanwaty melakukan penelitian tentang faktor determinan perilaku cuci tangan pakai sabun (CTPS) pada masyarakat di Tanah Kalikedinding dengan karakteristik responden pada penelitian menggambarkan jenis kelamin, umur, pendidikan, jenis pekerjaan, pengetahuan, sikap dan perilaku. Hasil dari penelitian ini menunjukkan bahwa mencuci tangan dengan benar dan memakai sabun ditentukan dari perilaku diri sendiri dalam menjaga kesehatannya, serta peran sikap dan perilaku CTPS mendukung tercapainya CTPS yang benar (Risnawaty, 2016). Kesehatan dan perilaku memiliki hubungan yang positif, seseorang yang sehat akan terlihat dari perilaku yang sehat pula. Sesuai dengan hal tersebut, maka perilaku yang sehat dapat menggambarkan kualitas hidup yang baik. Apabila kualitas hidup seseorang baik, dapat dikatakan bahwa orang tersebut memeiliki kesejahteraan dari segi kesehatan. Selain itu, fasilitas cuci tangan pakai sabun harus 
didukung dengan tersedianya air yang bersih dan berkucupan agar CTPS dapat terlaksana dengan baik.

c. Akses terhadap hunian layak dan terjangkau

Pemenuhan kesejahteraan atas papan (rumah/tempat tinggal) bersifat sangat urgen dan mendesak karena secara konstitusional, papan merupakan hak dasar yang terkait dengan hak asasi warga negara yang harus dipenuhi oleh pemerintah selaku representasi atas kehadiran negara (Prayitno, 2016). Jaminan kesejahteraan atas papan dengan adanya akses terhadap hunian layak dan terjangkau juga memberi pengaruh atas akses kebutuhan air. Apabila akses hunian bisa dijangkau oleh semua kalangan masyarakat, maka untuk hal akses kebutuhan air juga dapat terpenuhi. Oleh karena itu kesejahteraan dapat terjadi di kalangan masyarakat.

d. Status kepemilikan rumah milik sendiri

Penelitian tentang faktor pengaruh ketersediaan septictank, dimana status kepemilikan rumah menjadi salah satu indikatornya. Hasil penelitian tersebut menunjukkan bahwa status kepemilikan rumah tidak berhak milik berpotensi 3,903 kali tidak memiliki septictank dibandingkan dengan status kepemilikan rumah dengan hak milik sendiri (Swastika \& Dwipayanti, 2012). Kepemilikan septictank erat kaitannya dengan penyediaan sanitasi layak dan air bersih. Apabila suatu rumah dapat mencukupi kelayakan sanitasi dan air bersih dirumahnya, maka dapat dikatakan rumah tersebut sudah sejahtera.

e. Tingkat pengangguran terbuka

Penelitian yang dilakukan di Daerah Istimewa Yogyakarta untuk mengetahui faktorfaktor yang mempengaruhi kesejahteraan, menghasilkan salah faktor yang memberi pengaruh yaitu Tingkat Pengangguran Terbuka (TPT). TPT memberi pengaruh langsusng terhadap Indeks Pembangunan Manusia (IPM) dan secara tidak langsung melalui tingkat kemiskinan (Fibrian \& Widodo, 2016). Kesejahteran dan TPT memiliki sifat yang berbanding terbalik. Apabila kesejahteraan meningkat, maka TPT rendah dan sebaliknya begitu. Terjadinya pengangguran juga dapat berdampak pada pemenuhan kebutuhan hidup seseorang, termasuk kebutuhan air. Orang yang memiliki pekerjaan akan memiliki upah atau gaji, kemudian upah atau gaji tersebut digunakan untuk memenuhi kebutuhannya. Jika untuk memenuhi kebutuhan hidup saja seeorang tersebut tidak bisa, maka besar kemungkinan kebutuhan air dan lainnya juga tidak dapat terpenuhi.

f. Angka harapan hidup

Angka harapan hidup juga dapat menjadi tolak ukur kesejahteraan masyarakat. Akses sanitasi dan air minum akan sejalan positif dengan angka harapan hidup. Seiring dengan meningkatnya akses sanitasi dan air minum, makan akan terjadi juga peningkatan harapan hidup. Harapan hidup yang tinggi dapat menandakan kesejahteraan yang terjadi.

3. Perkembangan sosial-ekonomi

a. PDRB per kapita

Kondisi perkembangan sosial ekonomi masyarakat sangat menentukan tercapainya ketahanan air. Hal tersebut dapat dilihat dari kualitas air bersih yang tidak terlepas dari keadaan sosial ekonomi suatu masyarakat. Semakin baik kondisi suatu perekonomian masyarakat, berarti akan semakin baik pula tatanan hidupnya tak terkecuali kualitas air dirumahnya. Dikutip dari laporan (UNICEF, 2017), bahwa orang-orang Indonesia yang paling miskin dan masih tertinggal memiliki kesenjangan dalam memperoleh akses sanitasi dan air bersih diantara perkotaan dan pedesaan. Mengukur ketahanan air dari perkembangan ekonomi dapat menggunakan indikator PDRB (Produk Domestik Regional Bruto) ADHB per kapita. Demikian, PDRB per kapita dapat menggambarkan kondisi 
perekonomian masyarakat di suatu daerah dan dari kondisi tersebut dapat dilihat hubungan antara perekonomian dan akses air bersih serta sanitasi layak dalam mencapai ketahanan air.

b. Laju pertumbuhan penduduk

Penelitian yang dilakukan (Anggraini et al., 2013) diperoleh hasil bahwa pertumbuhan jumlah penduduk memiliki pengaruh dari segi kuantitas terhadap kebutuhan air bersih. Asumsi bahwa pertumbuhan penduduk meningkat dapat menyebabkan penggunaan air bersih juga meningkat.

4. Pencemaran air dan bencana terkait air

Air merupakan sumber daya terbarukan yang setiap saat terus ada dan diperbarui. Namun, seiring berjalannya waktu suplai air terus berkurang, meski kebutuhan akan air bersih terus meningkat. Disamping itu, pemenuhan akan kebutuhan air harus sejalan dengan keadaan air yang bersih dan terjamin untuk kesehatan. Sumber utama air dapat berasal dari tanah, sungai, danau atau rawa air tawar. Apabila sumber utama air tersebut tercemar, maka akan membahayakan kesehatan makhluk hidup yang menggunakannya. Saat sumber air utama tercemar, terjadi kehilangan fungsinya sebagai sumber air. Kelangkaan air bersih akan terjadi dimana-mana, karena sumber air utama sudah tidak dapat digunakan lagi akibat tercemar. Pencemaran air akan menjadi permasalahan untuk masyarakat dunia dalam ketahanan air.

5. Melestarikan ekosistem

a. Deforestasi netto di dalam dan di luar kawasan hutan

Ekosistem sangat penting bagi kehidupan semua makhluk hidup di bumi. Ekosistem terbagi menjadi dua, yaitu ekositem darat dan ekosistem perairan. Ekosistem darat menjadi tempat rantai makanan terbesar, dimana manusia juga terdapat didalamnya. Hutan telah menjadi ekosistem terbesar di darat. Fungsi hutan tidak hanya sebagai penyedia oksigen untuk makhluk hidup bernafas, tetapi juga sebagai penampung; penyerap; dan penyedia sumber air. Apabila ekosistem hutan tidak dilestarikan secara baik, maka hutan akan kehilangan fungsinya sebagai sumber oksigen dan sumber air. Manusia dan makhluk hidup tentu akan punah jika hutan sudah tidak berfungsi lagi. Saat ini ekosistem terbesar di darat tersebut terancam hilang akibat kebakaran hutan yang sebagian besar disebabkan oleh manusia akibat dari pembukaan lahan baru maupun penutupan lahan. Hal tersebut menjadi bencana dan malapetaka bagi manusia dan makhluk hidup lainnya. Hutan yang terus dibakar akan menyebabkan terjadinya krisis luas lahan hutan. Penurunan luas lahan hutan yang meningkat akan berdampak pada berkurangnya luas lahan serapan. Lahan serapan yang berkurang akan menyebabkan berkurangnya sumber air tanah, sehingga hal tersebut bisa menimbulkan krisis air.

\section{Ruang Lingkup Penelitian}

Penelitian ini mengkaji penyusunan indeks ketahanan air rumah tangga berdasarkan indikator peyusunnya dan melihat variabel yang memengaruhi nilai indeks ketahanan air rumah tangga. Penelitian ini menggunakan data cross section dengan mencakup 32 provinsi di Indonesia tahun 2018. Data yang digunakan adalah data sekunder yang bersumber dari data publikasi oleh Kementerian Lingkungan Hidup dan Kehutanan (KLHK) dan Badan Pusat Statistik (BPS). Penentuan indikator didasarkan pada aspek yang terdapat dalam definisi ketahanan air menurut UN-Water. 


\section{HASIL DAN PEMBAHASAN}

\section{Pembentukan Faktor dan Indeks Ketahanan Air Rumah Tangga di Indonesia}

Indeks ketahanan air rumah tangga di Indonesia dibentuk dari lima aspek yang terdapat dalam definisi ketahanan air menurut UN-Water (2013). Kelima aspek tersebut yaitu, pemenuhan kebutuhan air dan menjaga keberlangsungan hidup, kesejahteraan manusia, perkembangan sosial-ekonomi, pencemaran air dan bencana terkait air, serta melestarikan ekosistem. Dari aspekaspek tersebut kemudian dikembangkan menjadi 11 variabel yang akan diteliti. Lalu dilakukan uji KMO untuk melihat kelayakan data yang digunakan. Nilai KMO adalah sebesar 0,715, artinya data layak untuk dilakukan analisis faktor karena hasil statistik uji lebih dari 0,5.

Langkah berikutnya adalah mengetahui apakah variabel-variabel yang akan digunakan layak untuk dianalisis menggunakan uji MSA (Measure of Sampling Adequancy). Berdasarkan uji MSA, terdapat tujuh dari sebelas variabel yang memenuhi kriteria layak atau bernilai $\geq 0,5$ untuk selanjutnya dibuatkan indeks. Selain MSA yang sudah terpenuhi kriteria, perlu dilakukan pemeriksaan nilai communalities-nya. Nilai communalities lebih dari 0,5 , maka variabel memiliki korelasi yang kuat dengan faktor yang telah terbentuk.

Terdapat dua faktor yang terbentuk setelah di rotasi faktor. Faktor pertama terdiri dari variabel sanitasi layak, fasilitas cuci tangan dengan sabun dan air, hunian layak, dan deforestasi netto di luar dan di dalam kawasan hutan yang diberi nama faktor sarana air. Faktor kedua terdiri dari variabel air minum layak, Status kepemilikan rumah milik sendiri, dan PDRB yang diberi nama faktor sosial-ekonomi. Faktor sarana air mampu menjelaskan ketahanan air sebesar 50,391 persen. Sedangkan faktor sosial-ekonomi mampu menjelaskan ketahanan air sebesar 28,027 persen. Total persentase kumulatif dari kedua faktor adalah 78,417 persen dan sisanya sebesar 21,583 persen merupakan varians yang tidak bisa dijelaskan oleh kedua faktor diatas.

Tabel 1. Aspek IKART yang terbentuk

\begin{tabular}{|c|c|c|}
\hline Faktor & Aspek & Indikator \\
\hline \multirow[t]{4}{*}{ Sarana air } & Kesejahteraan umat manusia & Sanitasi layak \\
\hline & & Fasilitas cuci tangan dengan sabun dan air \\
\hline & & Hunian layak \\
\hline & Pencemaran air dan bencana terkait air & $\begin{array}{l}\text { Deforestasi netto Indonesia di dalam dan di luar } \\
\text { kawasan hutan }\end{array}$ \\
\hline \multirow[t]{3}{*}{$\begin{array}{l}\text { Sosial- } \\
\text { ekonomi }\end{array}$} & $\begin{array}{c}\text { Pemenuhan kebutuhan air dan menjaga } \\
\text { keberlangsungan hidup }\end{array}$ & Sumber air minum layak \\
\hline & Kesejahteraan umat manusia & Status kepemilikan rumah milik sendiri \\
\hline & Perkembangan sosial-ekonomi & PDRB per kapita \\
\hline
\end{tabular}

Model IKART yang terbentuk 
IKART penelitian ini dapat diinterpretasikan bahwa semakin tinggi nilai indeks ketahanan air rumah tangga maka semakin tinggi tingkat kecukupan rumah tangga dalam menjaga pemenuhan kebutuhan air untuk keberlangsungan hidupnya sehari-hari. Hal tersebut terjadi karena rumah tangga yang memiliki sarana air dan perekonomian yang baik dapat mendukung kecukupan keberlanjutan pemenuhan air di dalam kehidupannya dan begitupun sebaliknya. Berdasarkan model yang sudah terbentuk, maka dapat ditentukan nilai IKART untuk 32 Provinsi yang ada di Indonesia.

\section{Pemetaan Indeks Ketahanan Air Rumah Tangga di Indonesia}

\section{Gambar 1. Capaian IKA per provinsi tahun 2018}

Berdasarkan peta tematik tersebut, dapat diketahui kategori IKART tiap provinsi. Terdapat kategori kurang terpenuhi kebutuhan air, cukup terpenuhi kebutuhan air, dan terpenuhi kebutuhan air. Pulau Sumatera, sebagian besar provinsi memiliki IKART kategori cukup terpenuhi kebutuhan air, kecuali Provinsi Bengkulu, Jambi, dan Lampung yang masuk kategori kurang terpenuhi kebutuhan air, sedangkan Provinsi Kepulauan Riau dan Kepulauan Bangka Belitung masuk kategori terpenuhi kebutuhan air. Pulau Jawa, hampir semua Provinsi masuk kategori cukup terpenuhi kebutuhan air,

DKI Jakarta dan Provinsi di wilayah sampai bagian termasuk pada sampai terpenuhi Terdapat sangat tinggi pengkategorian di dimana Provinsi masuk kategori kebutuhan air dan

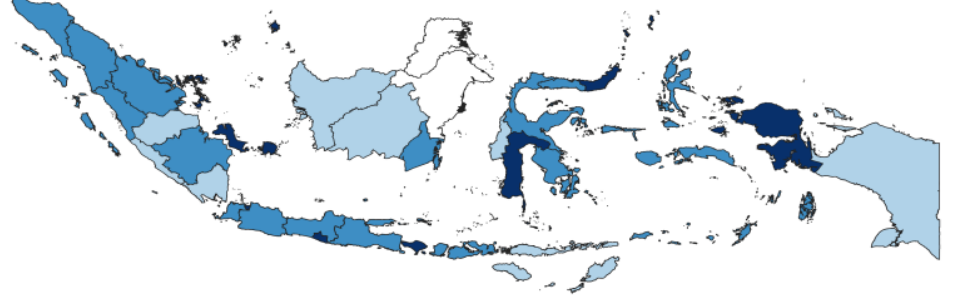

Tingkat Ketahanan Air Rumah Tangga Data tidak tersedia

tir (IKART $\leq 53,5425$ ) Cukup terpenuhi kebutuhan air ( $53,5425<$ IKART < 64,6625) Terpenuhi kebutuhan air (IKART $\geq 64,6625$ ) kecuali Provinsi DI Yogyakarta. bagian tengah timur Indonesia, kategori kurang kebutuhan air. perbedaan yang dalam

Pulau Papua, Papua Barat terpenuhi

Provinsi Papua kurang terpenuhi masuk kategori kebutuhan air. Provinsi Papua dan Provinsi lainnya yang masuk kategori kurang perlu menjadi prioritas pembangunan agar kebutuhan penduduk pada air terpenuhi dan ketahanan air dapat 
tercapai. Secara rata-rata Indeks Ketahanan Air Rumah Tangga yang dimiliki oleh Indonesia (32 Provinsi) sebesar 58,20.

Tabel 2. Peringkat 10 provinsi terendah menurut faktor pembentuk

Berdasarkan pada tabel tersebut, dapat diketahui provinsi-provinsi yang memiliki peringkat terendah pada setiap faktor. Pada faktor sarana air, dapat dilihat pada Lampiran 11, bahwa yang memiliki loading faktor tertinggi yaitu indikator fasilitas cuci tangan dengan sabun dan air sebesar 0,92. Jika dilihat dari hal tersebut, pemerintah pada provinsi yang telah disebutkan dapat memberikan pembangunan pada bidang sarana air. Data Badan Pusat Statistik (BPS) pada tahun 2017 menunjukkan bahwa proporsi populasi di Indonesia yang memiliki fasilitas cuci tangan dengan sabun dan air sebesar 78,87 persen. Provinsi dengan proporsi penduduk berfasilitas cuci tangan dengan sabun dan air tertinggi adalah Bali sebesar 92,78 persen. Provinsi Papua menjadi

\begin{tabular}{cll}
\hline \multirow{2}{*}{ Peringkat } & \multicolumn{1}{c}{ Saktor } \\
\cline { 2 - 3 } 32 & Sarana Air & \multicolumn{1}{c}{ Sosial-Ekonomi } \\
31 & Nusa Tenggara Timur & Bengkulu \\
30 & Riau & Sampung \\
29 & Kalimantan Barat & Maluku Utara \\
28 & Kalimantan Tengah & Kalimantan Barat \\
27 & Bengkulu & Nusa Tenggara Timur \\
26 & Jambi & Nusa Tenggara Barat \\
25 & Aceh & Kepulauan Bangka Belitung \\
24 & Sumatera Utara & Jawa Tengah \\
23 & DKI Jakarta & Maluku
\end{tabular}

terendah dengan angka 37,63 persen. Meskipun ada beberapa provinsi yang sudah mencapai angka 90 persen, namun masih banyak provinsi yang berada di bawah angka tersebut. Untuk mengatasi masalah tersebut, pemerintah sudah mencanangkan program Sanitasi Total Berbasis Masyarakat (STBM) sejak tahun 2008 melalui Departemen Kesehatan. Ada tiga intervensi yang dilakukan pemerintah yaitu meningkatkan akses terhadap sanitasi dasar, fasilitas cuci tangan pakai sabun dan air, dan pengelolaan air minum yang aman di rumah tangga. Tindakan lanjut yang dapat diberikan dari program tersebut adalah sosialisasi kepada masyarakat tentang betapa pentingnya sanitasi dan upaya dari masyarakat juga berperan untuk mewujudkan hal tersebut. Sedangkan pada faktor sosial ekonomi nilai loading faktor sebesar 0,92 terdapat pada indikator PDRB per kapita. Terdapat 7 dari 10 provinsi dalam peringkat rendah tersebut yang memiliki PDRB per kapita rendah dan sebagian merupakan berada di kawasan timur Indonesia. 


\section{KESIMPULAN}

Ketahanan air rumah tangga di Indonesia dapat diukur melalui variabel air minum layak, sanitasi layak, fasilitas cuci tangan dengan sabun dan air, hunian layak, status kepemilikan rumah milik sendiri, PDRB, dan deforestasi netto di luar dan di dalam kawasan hutan. Pada analisis faktor eksploratori yang dilakukan, terbentuk 2 faktor yaitu faktor sarana air dan faktor sosial-ekonomi. Wilayah dengan nilai indeks ketahanan air rumah tangga terendah berada pada Provinsi Papua dengan nilai 83,82 dan tertinggi berada pada Provinsi DKI Jakarta dengan nilai 83,82. Secara umum, masyarakat Indonesia memiliki ketahanan air rumah tangga yang berada pada tingkatan cukup-terpenuhi. Ada sebanyak 9 provinsi dengan kategori "kurang terpenuhi kebutuhan air", kemudian untuk kategori "cukup terpenuhi kebutuhan air" dan "terpenuhi kebutuhan air" masingmasing berjumlah 15 dan 8 provinsi.

\section{SARAN}

Saran yang dapat penulis berikan yaitu, pemerintah perlu melakukan pemerataan pembangunan infrastruktur khususnya di bidang air dan sanitasi. Selain itu, Pemerintah juga perlu meningkatkan kesadaran masyarakat Indonesia mengenai pencemaran lingkungan air dan pentingnya kawasan hutan sebagai salah satu sumber air di daratan. Untuk penelitian selanjutnya diharapkan penambahan variabel-variabel yang berkaitan dengan ketahanan air menurut definisi UN-Water misalnya pada pelestarian ekosistem dalam suasana damai dan kondisi politik yang stabil. Penambahan juga diharapkan pada jumlah provinsi dari 32 menjadi 34 provinsi, sehingga dapat menggambarkan ketahanan air secara keseluruhan di Indonesia

\section{DAFTAR PUSTAKA}

ADB. (2013). Asian Water Development Outlook 2013: Measuring Water Security in Asia and Pacific. In Asian Development Bank, Philippines.

Amron, M. (2010). Ketahanan Air dan Berbagai Tantangan Perubahan Iklim. Kementerian PUPR

Anggraini, F. D., Samadi, \& Warnadi. (2013). Pengaruh Pertumbuhan Penduduk Terhadap Kebutuhan Air Bersih di Pulau Panggang, Kelurahan Pulau Panggang, Kecamatan Kepulauan Seribu Utara, Provinsi DKI Jakarta. Spatial Wahana Komunikasi Dan Informasi Geografi, 12(2).

Asra, A., Utomo, A. P., Asikin, M., \& Pusponegoro, N. H. (2017). Analisis Multivariabel: Suatu Pengantar. In Media.

Faradis, R., \& Afifah, U. N. (2020). Indeks Komposit Pembangunan Infrastruktur Provinsi-Provinsi di Indonesia. Ekonomi Dan Pembangunan Indonesia, 20(1), 33-55.

Fibrian, F., \& Widodo, E. (2016). Analisis Jalur Terhadap Faktor-Faktor Yang Mempengaruhi Kesejahteraan Masyarakat di Daerah Istimewa Yogyakarta. Seminar Nasional Pendidikan Matematika Ahmad Dahlan.

Messakh, J. J., Sabar, A., Hadihardaja, I. K., \& Chalik, A. A. (2015). Kajian Pemenuhan Kebutuhan Air Minum Untuk Masyarakat Di Kawasan Semi-Arid Indonesia (A Study on Fulfillment of Drinking Water Need of People in Semi-Arid Areas in Indonesia). Jurnal Manusia Dan Lingkungan, 22(3), 271.

OECD. (2008). Handbook on Contructing Composite Indicators: Methodology and User Guides.

Pemerintah Pusat. (2019). Undang-undang Nomor 17 Tahun 2019 tentang Sumber Daya Air. Lembaga Negara RI Tahun 2019, No. 190. Sekretariat Negara. Jakarta.

Prayitno, B. (2016). Skema Inovatif Pemenuhan Kesejahteraan Atas Papan. Kawistara, 6(1), 47-61. 1092 
Risnawaty, G. (2016). Faktor Determinan Perilaku Cuci Tangan Pakai Sabun (CTPS) Pada Masyarakat di Tanah Kalikedinding. Promkes, 4 (1), 70-81.

Supranto, J. (2004). Analisis Multivariat: Arti dan Interpretasi. PT. Rineka Cipta.

Swastika, D. \& Dwipayanti, U. (2012). Faktor Pengaruh Terhadap Ketersediaan Septictankdan Sambungan Sewerage System Permukiman Pinggiran Kali, Kel. Dangin Puri, Denpasar. Archive of Community Health, 1(1), 55-62.

UN-Water. (2013). Water Security \&Global Water Agenda. A Un-Water Analytical Brief.

UNICEF. (2017). Air, Sanitasi dan Kebersihan. 